\title{
The Brandt report: better luck this time?
}

BLUEPRINTS for global survival have become an increasingly common fixture in popular debate over the past few years. Frequently presented with almost millenarian zeal, their appeal reflects an awareness that the growing interdependence of national economies has also nurtured potentially self-destructive tendencies of global proportions. The report* of the commission, headed by ex-West German prime minister Willy Brandt, suffers, like many of its predecessors, from a heavy overdose of idealism. But it deserves to be taken seriously, because it appears at a time when the stability of East-West and NorthSouth relations is more fragile than for the past twenty years.

In one sense the Brandt Commission - officially known as the Commission in International Development Issues - picks up where the Pearson Commission left off ten years ago. At that time, the main question was the appropriate level of development "aid" which the rich countries should provide to the poor; Pearson's answer was to set a target (which few countries have lived up to) of $0.7 \%$ of gross national product. Since then attention has shifted from the level of aid contributions to the conditions under which development can take place. And one way to read the Brandt Commission's report is as a reply to recent vocal demands for a "new international economic order".

The commission's message is that the development of a strong global economy will be of mutual benefit to rich and poor countries alike; but that this will not be achieved merely through the unfettered workings of the global market-place. What is recommended is almost a formula for an international welfare state. Political institutions, the commission argues, need to be developed which will protect the weakest actors on the international scene; bring order to the financial chaos which would result if market-forces were left unchecked; and seek redistribution of global wealth through international taxation.

As a prelude to this strategy, the report repeats a by-now familiar litany of the sad state of the world we live in. Furthermore, many of the specific proposals also carry a familiar ring. Some have already been heard from numerous multilateral aid bodies. Others are more often proposed by the developing countries themselves, and their espousal by a commission calls both for a massive transfer of resources from the developed to the developing nations, and for a strict code of conduct to regulate the activities of multinational corporations. At present both are being resisted, the former most recently at the Delhi meeting of the United Nations Industrial Development Organisation (UNIDO), which ended in stalemate earlier this month. There are other, less familiar, suggestions. For example, the commission devotes a chapter of its report on energy. It recommends that there should be a global energy research centre, established under UN auspices.

But it is in the field of economic reform that the commission makes some of its most far-reaching, controversial, proposals. Here the commission is calling for no less than the restructuring of international financing mechanisms, particularly to cope with the cash surpluses arising from the oil revenues of the OPEC countries. One of the most significant aspects of the redevelopment scene over the past decade, it points out, has been a shift from government-financed aid to loans from private banking and commercial institutions, many of which have used such loans as a way of recycling OPEC deposits.

The commission argues that this massive recycling has created instabilities in the system which the private sector may prove inadequate to control; and that the massive debt burden already carried by many Third World countries will inevitably dominate

* "North-South: A Programme for Survival" the Report of the Independent Commission on International Development Issues. Published by Pan Books, London, f1.95. development efforts for many years to come. Furthermore aid offered on commercial loan terms will tend to encourage relatively short-term development needs. But the commission is also critical of the stringent conditions laid down by the International Monetary Fund for loan assistance, arguing that these have often "tended to impose unnecessary and unacceptable political burdens on the poorest", and have led countries to prefer the private international banks.

The solution suggested by the Brandt Commission is to institutionalise ways of liberalising the international financing system. With respect to the IMF, for example, it suggests that the fund should "avoid inappropriate or excessive regulation" of the economies of the developing countries, and not impose "highly deflationary measures as standard adjustment policies". As far as the World Bank is concerned, the commission suggests, among other things, a shift to greater emphasis on programme loans, which would give a country flexibility in the methods it adopts to achieve a certain broad objective; it also suggests decentralising the bank's activities from Washington and giving a greater role in decision-making to representatives of the Third World.

Talking in realistic terms, any moves which would circumvent the role of existing financial institutions are certain to meet considerable opposition. Equally controversial is the suggestion for an international taxation system, all countries being assessed for their ability to pay into a general fund which would be made available for development purposes. The political appeal of such a system, possibly taking the form of a tax on international trade, is obviously limited; yet in his introduction to the report, Willy Brandt states that "by the end of the century the world will probably not be able to function without some practicable form of international taxation."

Those who followed last year's UNCSTD debate closely will not have missed the irony. For one of the major stumbling blocks in Vienna was the refusal of the developed countries to agree to the creation of a new fund, proposed by the developing countries to be based on contributions automatically assessed as a percentage of the trade in manufactured goods between rich and poor countries. It was merely agreed to establish an interim fund, based on voluntary contributions.

Indeed the commission's sketchy reference to the UNCSTD conference, grasping the inadequacy of its conclusions but providing little insight into why no more was achieved, merely illustrates the report's major weakness. For it is written more as a political manifesto than as a realistic framework for planning; but one that, given the growing attractions of protectionism and monetarist policies, lacks wide appeal at present. Furthermore the message that it is in the self-interest of the rich to promote the development of the poor inevitably invites the scepticism of those who would claim it as an expression of neo-imperialism.

But in one instance at least, the commission is correct. Suggesting that the industrialised countries restimulate their efforts to meet the aid targets to which many are already committed - and indeed to aim for $1 \%$ of GNP by the year 2000 - it adds that "what the neglect of foreign aid expresses is ultimately the lack of political priority attached to it." Next month in New York will see the pledging conference for the interim fund recommended by UNCSTD to finance new scientific and technological endeavours in developing countries, administered by the United Nations Development Programme. The event will indicate how much the main recommendations of the Brandt Commission have been taken to heart. Current indications are that total contributions will be less than initially hoped for although some countries - Britain excluded - will feel it appropriate to make reality of the Brandt Commission's analysis; and the acceptability of its message. 